\title{
Adıyaman İlinde Behçet Hastalığı: 150 Hastanın Retrospektif Değerlendirilmesi
}

\section{Behçet's Disease in Adıyaman Province: Retrospective Evaluation of 150 Patients}

\author{
Orhan ZENGIN 1 (D)
}

1 Dr. Ersin Aslan Eğitim ve Araştırma Hastanesi, Romatoloji Kliniği, Gaziantep, TÜRKIYE

Öz.

Amaç: Behçet hastalığı kronik sistemik bir vaskülittir. Çeşitli etnik ve bölgesel gruplarda prevalans ve klinik bulgular farklılık göstermektedir. Çalışmamızın amacı ülkemiz için endemik olan Behçet hastalığının, Güneydoğu Anadolu bölgesinde yer alan Adıyaman ilindeki verilerini sunmaktır.

Materyal ve metod: Romatoloji kliniğinde takipli Uluslararası Çalışma Grupları Tanı Kriterlerine (ISG) göre (1990) kriterlerine göre tanı konulmuş hastaların dosyaları retrospektif olarak taranarak klinik ve demografik özellikler kaydedildi.

Bulgular: Çalışmaya toplam 90'ı (\%60) erkek, 60'ı (\%40) kadın 150 hasta dahil edildi. Ortalama yaş $37,76 \pm 9,09$ idi. Klinik bulgularda oral aft \%100, genital ülser $82(\% 59,4)$, göz tutulumu $47(\% 35,6)$, cilt bulguları 34 (\%26) ve vasküler tutulum $16(\% 12,3)$ mevcuttu. Genital ülser kadınlarda, göz tutulumu ve cilt bulguları erkeklerde daha sık oranda görülmesine karşın istatiksel olarak anlamlı farkılık bulunmadı (sırasıyla $p=0,543, p=0,233, p=0,066$ ). Vasküler tutulum ise istatiksel olarak anlamlı oranda erkeklerde daha fazla mevcut idi $(p=0,048)$.

Sonuç: Çalışmamızda hastalarda en sık görülen bulgu mukokutanöz lezyonlardır. Ülkemiz verilerinde genç erkeklerde hastalığın daha ağır seyrettiği gözlenmiştir. Çalışmamızda vasküler tutulumun erkeklerde istatiksel olarak anlamlı derecede fazla olması, erkeklerde prognozun daha kötü olmasını açıklayabilir. Sonuç olarak çalışmamızın verileri Behçet hastalığının Güneydoğu'da, ülkemizdeki diğer bölgelerden bildirilen çalışmalara benzer klinik özellikler gösterdiğini düşündürmektedir.

Anahtar Kelimeler: Behçet hastalığı, Epidemiyoloji, Türkiye

\section{Abstract}

Background: Behçet's disease is a chronic systemic vasculitis. The prevalence and clinical findings differ among various ethnic and regional groups. Our study aims to present the data of Behçet's disease, which is endemic in our country, in Adıyaman province of Southeastern Anatolia.

Materials and Methods: The clinical and demographic characteristics of the patients were retrospectively evaluated according to the criteria of the International Study Group (1990) and followed in the rheumatology clinic.

Results: Our study included a total of 150 patients, including 90 (60\%) males, and 60 (40\%) females. The mean age was $37.76 \pm 9.09$ years. Clinical findings included oral aphthae (100\%); genital ulcers, 82 (59.4\%); eye involvement, 47 (35.6\%); skin findings, 34 (26\%); and vascular involvement, 16 (12.3\%). Although genital ulcers were more common in women and eye involvement and skin findings were more common in men, there was no statistically significant difference $(p=0.543, p=0.233$, and $p=0.066$, respectively). Vascular involvement was significantly higher in men $(p=0.048)$.

Conclusion: The most common finding in our study is mucocutaneous lesions. In our country's data, it was observed that Behçet's disease was more severe in young men. In our study, the fact that vascular involvement was significantly higher in men might explain the poor prognosis in men. As a result, our resuts suggest that Behçet's disease in the Southeast has similar clinical features as those reported from other regions in our country.

Key words: Behçet's disease, Epidemiology, Turkey

\section{Sorumlu Yazar I \\ Corresponding Author}

\section{Dr. Orhan ZENGIN}

Dr. Ersin Aslan Eğitim ve Araştırma Hastanesi, Romatoloji Bölümü, Gazi Muhtar Paşa Blv. No:37, 27090 Şehitkamil/Gaziantep, Türkiye. Tel: +90 3423241111

Faks: +903423241617

e-mail: drorhanzengin@gmail.com

Geliş tarihi / Received: 10.06.2020

Kabul tarihi / Accepted: 09.09.2020

\section{DOI: 10.35440/hutfd. 750305}

Bu çalışma 6 Haziran 2020'de Burdur Mehmet Akif Ersoy üniversitesinin düzenlediği 3. Uluslararası Sağıık Bilimleri ve Yaşam Kongresinde sözel bildiri olarak sunulmuştur. 


\section{Giriş}

Behçet hastalığı $(\mathrm{BH})$, ataklarla seyreden, kronik sistemik bir hastalıktır (1). Hastalık ilk kez 1937 yılında Dr. Hulusi Behçet tarafından tanımlanmıştır (2). BH patogenezinde genetik olarak yatkın kişilerde, viral, bakteriyel vb. gibi çevresel bir antijenle ve/veya oto antijenlerle tetiklenen düzensiz bir immün yanıt olduğu düşünülmektedir $(3,4)$.

Behçet hastalığında başta cilt ve mukoza tutulumu olmakla birlikte ek olarak göz, vasküler, eklem, nörolojik, gastrointestinal sistem tutulumları gösterebilmektedir. BH tüm dünyada görülmektedir ancak tarihi "İpek Yolu" üzerindeki ülkelerde daha sıktır. Prevalansının en yüksek olarak bildirildiği ülke ise Türkiye'dir $(5,6)$. BH tanısı klinik kriterler temel alınarak konulur. Tanıda en çok uluslararası çalışma grubu (ISG) kriterleri kullanilır (7).

Behçet klinik bulguları etnik köken ve çevresel faktörlerden oldukça fazla etkilenmektedir. Farklı ülkelerde ve bölgelerde değişen oranlarda sistemik tutulumlar bildirilmiştir. Biz de bu çalışmada Adıyaman şehrinde $\mathrm{BH}$ tanısıyla takip edilen hastaların demografik ve klinik özelliklerinin ortaya konarak, ülkemiz ve dünya verileriyle kıyaslanmasını amaçladık.

\section{Materyal ve Metod}

Bu çalışmada, romatoloji polikliniğinde takipli Uluslararası Çalışma Grupları Tanı Kriterlerine (ISG) göre BH tanıSı konmuş hastaların dosyaları retrospektif olarak tarandı. iSG'ye göre (1990): Oral aftöz ülserlere ek olarak (12 ayda en az 3 defa herhangi bir şekil, boyut ve sayıda) aşağıdaki 4 majör belirtilerden az 2 tanesi:

1. Genital ülserler

2. Deri lezyonları (Papülo-püstüller, folikülit, eritema nodozum, kortikosteroidlere bağlı olmayan ergenlik sonrası dönemdeki akne)

3. Göz enflamasyonları (Iritis, üveitis, retinal vaskülitis, vitritis)

\section{Paterji reaksiyonu bulunmalıdır (7).}

Çalışmaya 18 yaş üstü tüm hastalar alındı ve çalışmaya toplam 150 hasta dahil edildi. Hastaların demografik özellikleri, tanı anındaki yaşları, klinik bulguları, paterji testi, HLA-B51 pozitifliği, aile öyküsü, tanı aldıktan sonraki tedaviler ile tedavi yanıtları, ilaçlara bağlı gelişen komplikasyonlar değerlendirildi. Hastalar organ tutulumuna göre; mukokütanöz, oküler, vasküler, enteral ve nörobehçet olmak üzere alt gruplara ayrıldı.

Çalışma için etik kurulu onayı Adıyaman Üniversitesi Klinik Çalışmalar Etik kurulundan 2018/8-1 nolu karar ile alınmıştir.

Istatistiksel analizler SPSS versiyon 20 yazılımı ile yapıldı. Değişkenler ile normal dağııım arasındaki ilişki analitik yöntemlerle (Kolmogorov-Smirnov) incelendi. Tanımlayıcı veriler ortalama ve standart sapma veya sayı (\%) olarak verilmiştir. Gruplar arası değerlerin karşılaştırmasında
Ki-kare ya da Fisher testi kullanıldı. Gruplar arasında sürekli değişkenlerin karşıllaştırımasında Student t testi kullanıldı. $p<0,05$ değeri anlamlı olarak kabul edildi.

\section{Bulgular}

Çalışmaya toplam 150 hasta dahil edildi. Hastaların 90'ı (\%60) erkek, 60'ı (\%40) kadındı. Ortalama yaş 37,76 \pm 9,09 idi. Illk semptomdan tanı almalarına kadar geçen süre (tanıda gecikme süresi) ortalama 2,99 $\pm 1,26$ yıldı. Behçet hastalığı tanısını alma yaşı ortalaması ise 33,01 \pm 6,41 idi. HLA B51 hastaların 55'inde çalışıımıştı, 20 hastada $(\% 36,4)$ pozitifti. Ailesinde Behçet hastası olanların oranı $\% 6,6$ idi $(n=10)$ (Tablo 1).

Klinik bulgular açısından değerlendirildiğinde oral aft \%100 ile en sık bulguydu. Oral aftı sırasıyla genital ülser 82 $(\% 59,4)$, göz tutulumu $47(\% 35,6)$, cilt bulguları $34(\% 26)$ (\%11,5 eritema nodozum, \%14,5 psödofollikülit), artrit 33 $(\% 24,8)$, vasküler tutulum $16(\% 12,3)$ ve nörolojik tutulum $5(\% 3,8)$ izlemekteydi. En az gastrointestinal tutulum mevcuttu $1(\% 0,8)$. Hastaların 104 'ne paterji yapılmışı ve 26 'sında (\%25) pozitif idi (Tablo 1 ).

Tablo 1. Hastaların demografik ve klinik özellikleri

\begin{tabular}{ll}
\hline & Hastalar (n=150) \\
\hline Yaş & $37,76 \pm 9,09$ \\
Einsiyet & $90(\% 60)$ \\
kadık & $60(\% 40)$ \\
Tanı yaşı & $33,01 \pm 6,41$ \\
Tanıda gecikme süresi (yıl) & $2,99 \pm 1,26$ \\
Ailede behçet öyküsü & $10(\% 6,6)$ \\
HLA B51 pozitifliği & $20(\% 36,4)$ \\
Oral aft & $150(\% 100)$ \\
Genital aft & $82(\% 59,4)$ \\
Göz tutulumu & $47(\% 35,6)$ \\
Eritema nodozum ve/veya psödofolikülit & $34(\% 26)$ \\
Artrit & $33(\% 24,8)$ \\
Vasküler tutulum & $16(\% 12,3)$ \\
Nörolojik tutulum & $5(\% 3,8)$ \\
Gastrointestinal tutulum & $1(\% 0,8)$ \\
Paterji pozitifliği & $26(\% 25)$ \\
\hline
\end{tabular}

Değerler ortalama \pm standart sapma veya sayı (\%) olarak verilmiştir.

Tedavide ilaçlardan en fazla kullanılanı 114 hasta $(\% 88,4)$ kolşisin idi. Onu sırasıyla $62(\% 48,1)$ azatioprin, steroid 62 $(\% 48,1), 12(\% 9,3)$ siklosporin, $9(\% 7)$ interferon-alfa, 5 $(\% 3,9)$ metotreksat, $5(\% 3,9)$ varfarin, $4(\% 3,1)$ siklofosfamid, 3 (\%2,3) adalimumab, $2(\% 1,6)$ asetilsalisilik asit, 2 $(\% 1,6)$ infliksimab, $2(\% 1,6)$ sülfasalazin izlemekteydi. Kolşisin tedavisi alan hastalarda ishal en sık görülen yan 
etki idi. Steroid kullanan hastalarda GIS yakınmaları, kilo alımı, akne yakınmaları (\%13) gözlemlenmiştir. Steroid alan $3(\% 2,3)$ hastada avasküler nekroz gelişmişti.

Hastalar cinsiyete göre karşılaştıııldı̆ında yaş, tanı yaşı, tanıda gecikme süresi, HLA B51 pozitifliği, artrit sıklığı, nörolojik tutulum ve paterji pozitifliği benzerdi. Genital ülser kadınlarda, göz tutulumu ve cilt bulguları (eritema nodozum ve psödofollikülit) erkeklerde daha sık oranda görülmesine karşın istatiksel olarak anlamlı farkılık bulunmadı (sırasıyla $p=0,543, p=0,233, p=0,066$ ). Vasküler tutulum ise istatiksel olarak anlamlı oranda erkeklerde daha fazla mevcut idi $(p=0,048)$ (Tablo 2).

Tablo 2. Cinsiyete göre hastaların klinik ve demografik özelliklerinin karşılaşıııııası

\begin{tabular}{llll}
\hline & $\begin{array}{l}\text { Erkek } \\
(\mathbf{n}=90)\end{array}$ & $\begin{array}{l}\text { Kadın } \\
(\mathbf{n}=60)\end{array}$ & p değeri \\
\hline Yaş & $37,74 \pm 9,35$ & $37,78 \pm 8,75$ & 0,293 \\
Tanı yaşı & $33,52 \pm 6,59$ & $32,28 \pm 6,13$ & 0,299 \\
$\begin{array}{l}\text { Tanıda gecikme süresi } \\
\text { (yıl) }\end{array}$ & $3,23 \pm 1,50$ & $2,67 \pm 0,76$ & 0,307 \\
HLA B51 pozitifliği & $14(\% 37,8)$ & $6(\% 33,0)$ & 0,110 \\
Oral aft & $90(\% 100)$ & $60(\% 100)$ & 0,184 \\
Genital aft & $47(\% 57,3)$ & $35(\% 62,5)$ & 0,543 \\
Göz tutulumu & $31(\% 39,7)$ & $16(\% 29,6)$ & 0,233 \\
$\begin{array}{l}\text { Eritema nodozum } \\
\text { ve/veya psödofolikülit }\end{array}$ & $24(\% 29,9)$ & $11(\% 20,4)$ & 0,066 \\
Artrit & $19(\% 24,7)$ & $14(\% 25)$ & 0,966 \\
Vasküler tutulum & $13(\% 17,1)$ & $3(\% 5,6)$ & $0,048^{*}$ \\
Nörolojik tutulum & $3(\% 5,7)$ & $2(\% 2,6)$ & 0,547 \\
Paterji pozitifliği & $17(\% 25,8)$ & $9(\% 23,7)$ & 0,814
\end{tabular}

$\overline{\text { Değerler ortalama } \pm \text { standart sapma veya sayı (\%) olarak verilmiştir. }{ }^{*} p<0,05}$ istatistiksel olarak anlamlı kabul edildi.

\section{Tartışma}

Behçet Hastalığı kronik seyirli, vaskülit temelli inflamatuar bir hastalıktır. Çeşitli etnik ve bölgesel gruplarda BH'nın prevalansı ve klinik bulguları farklılık göstermektedir $(8,9)$. Bu çalışmanın amacı ülkemiz için endemik olan Behçet hastalığının, Güneydoğu Anadolu bölgesinde yer alan bir ilin verilerini sunmaktır.

Hastalık 20-40 yaş arası genç erişkinlerde daha sıkıkla görülmektedir. BH başlangıç yaşı çoğunlukla 24.7 ile 35,2 arası bildirilmiştir $(10,11)$. Bizim çalışmamızda hastaların ortalama tanı yaşı $33,01 \pm 6,41$ idi. Ortalama tanıda gecikme süresi 2,99 $\pm 1,26$ yıl idi. Hastalar cinsiyete göre karşılaştııılığında tanı yaşı ve tanıda gecikme süresi açısından anlamlı farklıık yoktu.

BH tüm dünyada görülmekle Türkiye, İran ve Uzak Doğu ülkeleri hastalığın en sık görüldüğü ülkelerdir. Ülkemizde Behçet'le ile ilgili yapılan çalışmalarda prevalans çeşitli bölgelerde 8-42/10000 arasında bulunmuştur $(8,12)$. Oral
\%92-100 ve genital ülserler \%57-93 tüm ülkelerde hastalığın en sık görülen klinik özellikleridir. Ülkemizde genital ülser sıklığı \%70.2- \%88.2 olarak bildirilmiştir $(7,13)$. Bizim çalışmamızda oral aft oranı \%100 iken genital aft \%59,4 oranında bulunmuş olup önceki çalışmalara benzerdir. Cilt lezyonlarından en sıkı görülenleri başlıca eritema nodozum ve papülopüstüler/akneiform lezyonlardır. Papülopüstüler lezyonları akneden ayırmak zordur ve vücudun herhangi bir yerinde olabilirler (14). Ülkemizdeki yapılan çalışmalarda papülopüstüler döküntüler $\% 55.4-\% 59.5$ oranında bildirilmiştir. Eritema nodozum ise Türkiye verilerinde \%44.2-45.5 arasında bildirilmiştir $(2,15)$. Bu çalışmada eritema nodozum sıklığı \%11,5, papülopüstüler lezyonlar $\% 14,5$ oranında saptandı ki bu değerler ülkemiz verilerine göre düşük görünmektedir.

Behçet'in klasik tutulum yerlerinde olan göz tutulumu Ortadoğu'da \%28.9-76 ve Avrupa'da \%35-92 oranında bildirilmiştir. Göz tutulumunda en sık şekli olan Behçet üveiti genellikle 3. dekatta başlar ve erkeklerde daha sıktır $(13,16)$. Bizim çalışmamızda da bu verilere uyumlu şekilde göz tutulumu hastaların \%35,6'inde tespit edilmiştir.

Behçet'te kas iskelet sistemi tutulumu ana klinik özelliklerden biridir. Artrit genellikle intermitan, non-eroziv ve monoartikülerdir. Eklem tutulumu farklı ülkelerde \%40-70 arasında değişen oranlarda bildirilmiştir (17-19). Mevcut çalışmada artrit sıkığı \%24,8 gibi azımsanmayacak oranda bulunmuştur. Bu sonuç bize Behçet kliniğinde klasik tutulumların yanında artritin de göz ardı edilmemesi gerektiğini göstermektedir.

Vasküler tutulum Behçet'te morbidite ve mortalitenin majör nedenlerindendir. Literatürde çalışmalarda $\% 1,8-\% 57,1$ arasında değişen oranlarda vasküler tutulum bildirilmiştir. Daha önce yapılan Ortadoğu kökenli çalışmalarda \%17$\% 40$, Uzak Doğu ülkelerinde \%1,8-\%11 oranlarında değişmektedir $(20,21)$. Bizim çalışmamızda olguların 16'sında $(\% 12,3)$ vasküler tutulum mevcuttu. Bu veri, Ortadoğu ülkeleri ile benzerlik gösteriyordu. BH'da tanı kriterlerinden olan nörolojik tutulum hastalığın en ciddi klinik tablolardan biridir. Literatürde tutulum sıklığı oldukça değişken oranlarda bildirilmiştir. Türkiye verilerinde bu oran yaklaşık $\% 5$ $\% 7$ arasındadır (22). Bizim çalışmamızdaki oran $\% 3,8^{\prime}$ dir. Bu sonuç daha önceki Türkiye çalışmalarında olduğu gibi diğer ülke verilerine göre düşük orandadır.

BH'da klinik bulgular cinsiyete göre farklılık gösterebilmektedir. Daha önce ülkemizde yapılan çalışmalarda kadınlarda genital ülser ve eritema nodozum daha fazla iken, erkeklerde papülopüstüler lezyonlar, tromboflebit, oküler, nörolojik, pulmoner ve vasküler tutulum daha fazla olduğu bulunmuştur. Ayrıca genç erkeklerde hastalığın daha ağır seyrettiği gözlenmiştir $(2,23,24)$. Bu çalışmada erkek hasta sıklığı (\%60) kadınlardan (\%40) fazlaydı. Hastalar cinsiyete göre karşılaştırıldığında artrit sıklığı, nörolojik tutulum ve paterji pozitifliği benzerdi. Genital ülser kadınlarda, göz 
tutulumu ve cilt bulguları erkeklerde daha sık oranda görülmesine karşın istatiksel olarak anlamlı farklıık bulunmadı. Vasküler tutulum ise istatiksel olarak anlamlı oranda erkeklerde daha fazla mevcut idi $(p=0,048)$. Vasküler tutulumun kadınlara nazaran erkeklerde fazla olması erkelerde prognozun daha kötü olmasını açıklayabilir.

Bu çalışmada Adıyaman'da romatoloji kliniğinde izlenmiş hastaların demografik ve klinik bulguları sunulmuştur. Olgularımızda mukokutanöz bulguların ön planda olduğu, bunun yanında önemli ölçüde göz tutulumu, eklem tutulumu ve vasküler tutulum olduğu görülmüştür. Bu bulgular Behçet'in Güneydoğu'da, ülkemizdeki diğer bölgelerden bildirilen çalışmalarla benzer klinik özellikler gösterdiğini düşündürmektedir.

Çalışmamızın bazı kısıttılıkları göz önünde bulundurulmaIıdır. Hasta sayısının az olması dışında HLA-B51 ve paterji gibi testlerin her hastaya yapılmamış olması kısıttlıık olarak düşünülebilir. Ayrıca daha uzun takip süreli hasta verileri prognoz ve tedavi yanıtları açısından daha yol gösterici olabilir.

Etik onam: Çalışma için etik kurulu onayı Adıyaman Üniversitesi Klinik Çalışmalar Etik kurulundan 2018/8-1 nolu karar ile alınmıştır.

\section{Kaynaklar}

1. Zierhut M, Mizuki N, Ohno S, Inoko H, Gül A, Onoé K et al. Immunology and functional genomics of Behcet's disease. Cell Mol Life Sci. 2003;60(9):1903-22.

2. Tursen U, Gurler A, Boyvat A. Evaluation of clinical findings according to sex in 2313 Turkish patients with Behcet's disease. Int J Dermatol. 2003;42(5):346-51.

3. Alpsoy E. Behçet Hastalığının Deri ve Mukoza Belirtileri. Türk Deri Hastalıkları ve Frengi Arşivi. 2003;37(2):92-9.

4. Alpsoy E, Akman A. Behçet Hastalığı; Etyopatogenezde Yeni Kavramlar. Türkiye Klinikleri J Int Med Sci. 2007;3(9):8-14.

5. Azizlerli G, Köse AA, Sarica R. Prevalence of Behcet's disease in Istanbul, Turkey. Int J Dermatol. 2003;42(10):803-6.

6. Kural-Seyahi E, Fresko I, Seyahi N. The long-term mortality and morbidity of Behcet syndrome: a 2-decade outcome survey of 387 patients followed at a dedicated center. Medicine (Baltimore). 2003;82(1):60-76. 7. International study group for Behçet's disease. Criteria for diagnosis of Behçet's disease. Lancet. 1990;335(8697):1078-80.

8. Evereklioglu $\mathrm{C}$. Current concepts in the etiology and treatment of Behcet disease. Surv Ophthalmol. 2005;50(4):297-350.

9. Pamuk ÖN, Çakır N. Behçet hastalığı epidemiyolojisi. Türkiye Klinikleri J Int Med Sci. 2005;1(25):3-9.

10. Hegab S, Mutava S. Immunopathogenesis of Behçet's disease. Clin Immunol. 2000;96(3):174-86.

11. Bang DS, Oh SH, Lee KH, Lee ES, Lee SN. Influence of sex on patients with Behçet's disease in Korea. J Korean Med Sci. 2003;18(2):231-5.

12. Karincaoglu Y, Coskun BK, Seyhan M, Aki T. Demographical and clinical characteristics of Behçet's disease patients in Malatya and Elazig. Turkiye Klinikleri J Dermatol. 2005;15(2):65-70.

13. Saylan T, Mat C, Fresko I, Melikoglu M. Behçet's disease in Middle East. Clin Dermatol. 1999;17(2): 209-23.

14. Yazıcı H, Hekim N, Tüzün Y, Serdaroğlu S, Kotoğyan A, Öz F et al. Sex factors in Behçet's syndrome. International Conference of Behçet's Disease, London.1986;103:205-6.

15. Alpsoy E, Dönmez L, Önder M, Günastı S, Usta A, Karıncaoglu Y.
Clinical course of Behçet's disease in 661 cases: a multicenter study. $\mathrm{Br}$ J Dermatol. 2007;157(5): 901-6.

16. Zouboulis CC, Kötter I, Djawari D, Kirch W. Epidemiological features of Adamantiades-Behçet's disease in Germany and in Europe.Yonsei Med J. 1997;38(6): 411-22.

17. Yurdakul S, Yazici H, Tüzün Y,Pazarlı H, Yalçın B, Altaç M et al. The arthritis of Behçet's disease: a prospective study. Ann Rheum Dis. 1983;42(5):505-15.

18. Kim HA, Choi K W, Song YW. Artropathy in Behçet's disease. Scand J Rheum. 1997;26(2):125-9.

19. Benamour S, Zerouol B, Alaou FZ. Joints manifestations in Behçet's disease: A review of 340 cases. Rev Rheum. 1998;65(5):299-307.

20. Bang D, Lee J, Lee E, S Lee, J S Choi, Y K Kim et al. Epidemiological and clinical survey of Behcet's disease in Korea: the first multicenter study. J Korean Med. Sci 2001;16(5):615-8.

21. El Menyawi MM, Raslan HM, Edrees A. Clinical features of Behcet's disease in Egypt. Rheumatol Int. 2009;29(6):641-6.

22. Akman-Demir G. Behçet Hastalığında Nörolojik Tutulum. Turkderm. 2009;43(2):61-4.

23. Yazici H, Tuzun Y, Pazarli H, S Yurdakul, Y Ozyazgan, H Ozdoğan et al. Influence of age of onset and patient's sex on the prevalence and severity of manifestations of Behcet's syndrome. Ann Rheum Dis. 1984;43(6):783-9.

24. Balta I, Akbay G, Kalkan G, Eksioglu M. Demographic and clinical features of 521 Turkish patients with Behcet's disease. Int J Dermatol 2014;53(5):564-9. 